\title{
Indonesian Vocabulary Mastery of Early-aged Children in Paud Melati Makassar
}

\author{
Asia \\ Universitas Negeri Makassar, Jln. Bonto Langkasa, Kampus Gunung Sari, Makassar, South Sulawesi, Indonesia \\ Achmad Tolla \\ Universitas Negeri Makassar, Jln. Bonto Langkasa, Kampus Gunung Sari, Makassar, South Sulawesi, Indonesia
}

Salam

Universitas Negeri Makassar, Jln. Bonto Langkasa, Kampus Gunung Sari, Makassar, South Sulawesi, Indonesia

\begin{abstract}
Early-aged children are individuals from 0 to 6 year old with unique characteristics and in the stage of growth and development, both physical and mental. Several aspects developed for their education include moral and religious values, social, emotional feelings, autonomy, language, cognitive, physical/motor skill, and art (Ramli, 2005, p.50). The development of these aspects affect each other, that is why it has to be optimally developed in every activity. One aspect of those basic skills should be developed in early-aged children is language. The objectives of this research are to describe (1) the quantity of Indonesian vocabularies in earlyaged children; (2) certain Indonesian word classes in early-aged children; (3) certain scopes of Indonesian vocabularies in early-aged children; (4) Indonesian basic sentence pattern in early-aged children; (5) Indonesian basic sentence features considered by the form of integrative phrases; (6) Indonesian basic sentence features considered by the number of integrative phrases. The results of the research show that the vocabulary quantity of early-aged children varies due to external and internal factors. It triggers their inputs to vary from one to another. Word classes mastered by them include noun, verb, adjective, adverb, numeral, pronoun, and preposition. Based on the findings in the field, they have also mastered several vocabulary scopes, such as kinship, activity, place, number, color, universal objects, and animal types. In line with that, sentence patterns that have been mastered by them are $F N-F V, F N 1-F N 2, F N-F A, F N-N u m$, and $F N-F P$.
\end{abstract}

Index Terms - vocabulary mastery, early-aged children

\section{INTRODUCTION}

Early-aged children are those wih the age range from 0 to 6 year old. They undergo a rapid and fundamental process of growth and development for the next phase of life. In these years, they have as what is called as sensitive period where they are specifically easy to receive stimulation. Main developments occurred during this period revolves around certain mastery and environmental control or commonly referred to the period of exploration. Children want to know the state of their environment, how the mechanism, how it feels, and how they can blend with their environment (Hartati, 2005, p.7).

Those early-aged children are in the most rapid stage of growth and development, both physical and mental (Suyanto, 2005, p.5). Then it is appropriate to state that early age is the golden age, where they are significantly potential to learn many things quickly. Vocabulary mastery plays an important role in developing aspects of language skills. A child who masters vocabulary, will be able to speak well and fluently. The vocabulary mastery has an ultimate function in a child's development. It is because those children who master lots of vocabulary tend to have self-confidence and are able to influence their peers to behave as they wish than those children with limited vocabulary (Hamboro 1995, p.43). Several mastery efforts of children's basic vocabulary skills can be done through the provision of stimulus from an early age. By doing so, it is expected that their skills in language will be better developed and their vocabulary will be also increased.

Vocabulary mastery plays an important role in developing aspects of language skills. A child who mastered the vocabulary well, then the child is easily able to speak well and fluently. A better vocabulary mastery also greatly affects the ability of children to communicate in both oral and written. With enough vocabulary, the child is more likely to express his thoughts, ideas, and feelings to others. Children who learn vocabulary from an early age will be trained in related language because the child's brain has been embedded of various kinds of vocabulary. The language that they possess can not be separated from the number of vocabularies they have masterd. Children who master lots of vocabularies will hardly face difficulties in speaking and delivering sentences or in the form of language.

Pursuing this further, vocabulary mastery is one of the main conditions which determines personal success in language skills. Tarigan (1984, p.109) states that an individual's language skills depend on the quantity and quality of his vocabulary. The richer vocabulary a man has, the greater possibility for him to be skilled at speaking. Learning a 
language means learning vocabulary. It intends that vocabulary is the most important element in a language. A language is meaningful because the existence of its vocabulary. That is why the ability of one's language is vital. It can affect the ability of thinking and learning process in children's life.

\section{A. Early-aged Children}

A child is a small form of human beings with potentials to develop. They have certain unique characteristics which makes them different from adults, but then also will develop into a complete human adult. According to Law on National Education System (2003), "early-aged children are those in the age range of 0-6 years". They have certain unique characteristics unlike adults. They are always active, dynamic, enthusiastic and curious about what they see and hear, as if they have never stopped learning. Mansur (2005, p.88) reveals that "early-aged children is a group of children who are in a special growth and development process according to its extents".

In line with this, Hartati (2005, p.7) also reveals that "early-aged child is a human or individual who has a particular pattern of development and needs which is different from adults". It is also added by Mulyasa (2012, p.16) that earlyaged child is an individual who is experiencing the process of growth and rapid development with the amazing progress. One similar statement from Mustafa $(2002$, p.35) is that early-aged children are those who defined as ages one to five years. This understanding is based on limitation of developmental psychology includes infancy or babyhood from $0-1$ years, early childhood, and children with age range from 6-12 years.

Furthermore, Bredekamp (1992, p.6) classifies early-aged children into three, that is infant group (0-2 years), children group with ages of three to five years, and children with ages of 6-12 years. Early age period in the course of human life is an important period for brain growth, intelligence, personality, memory, and other aspects of development.

Early age is the period of growth which determines future. Once the importance of early age, Freud (in Ramli, 2005, p.2) argues that early age is an important and unique event, which then forms the foundation for the structure of human personality. The age of kindergarten is one of the age range of early age, that is from ages of 4 to 6 years (Depdiknas, 2009, p.1).

As mentioned earlier, it can be concluded that early-aged children are individuals with ages from 0-6 years who have unique characteristics and in the stage of growth and development, both physical and mental. Early-aged children education will help the process of growth and development into a better human being or well maturity.

The period of children at an early age is a stage of development that lasts from the end of infancy to the age of five to six years. At this stage, many children take the time to play alone or perform various activities with his friends for their development. During this stage, children also individually learn to do all things related to the skills for school preparation. Furthermore, Krathwohl (in Lubis, 2009) in his book of Evaluation of Values Education states that the process of forming values in children can be divided in five stages: 1) receiving stage; (2) responding stage; 3) valuing stage; 4) organizing value stage; and 5) characterization stage. These five stages support each other for achieving maximal value creation in children.

\section{B. Characteristics of Early-aged Children}

Cross in Madyawati (2016, p.16) argues that there are several characteristics of early-aged children as follows:

1. Egocentrism

A child sees outside world from his own view, according to his own knowledge and understanding, limited by his narrow feelings and thoughts. Children are so influenced by their simple minds that they are unable to penetrate the feelings and thoughts of others. They are incapable to understand the true meaning of an event and place themselves in others' life or mind. They are very attached to themselves and consider that their personality is one and closely integrated with their environment which make them cannot be separated from it.

2. Unique Characteristic

Each child is different. Children have different innate, interest, capabilities, and life background. Although there is a general pattern of sequences in child development that can be produced, the patterns of development and learning still differ from one another.

3. Spontaneous Expression or Behavior

The behaviors that children show are commonly genuine or not covered up. They will get angry or cry if they want to. They show a cheerful expression in joyful moment and mournful expression when they sad, no matter where they are or with whom.

4. Being Active and Energetic

Children love to do various activities. As long as they stay awake, they will never stop or get tired from activities and rarely bored. Especially when they deal with a new and challenging event. Motion and activity for them is something that involves physical movement rather than sitting and paying attention to their teacher.

5. Strong Curiosity and Enthusiasm for Things

This behavioral characteristic stands out at the ages of 4-5 years. Children of this age concern, talk, and question various things that they have seen and heard, especially new things.

\section{Vocabulary Mastery}


Vocabulary mastery is very important in language. The richer vocabulary a man has, the greater possibility for him to be skilled at speaking or language (Tarigan, 1989, p.23). In line with that, Jamaris (2005, p.43) also suggests that the ability of vocabulary mastery is divided into two kinds, that is receptive and productive mastery. Receptive mastery is the process of understanding spoken language by others. It is defined as passive mastery. While productive mastery is the process of communicating ideas, thoughts, and feelings through form of vocabulary. Vocabulary mastery in daily activities or life has a very big role, because one's thoughts can only be clearly understood by others if expressed by using vocabulary. Furthermore, Pustejovsky in Jamaris $(2005$, p.12) confirms that a person's language capacity is a reflection of his ability to classify and show the meaning of a particular word.

\section{Theories of Language Mastery}

\section{Theories of Behaviorism}

This theory was pioneered by Skinner (1957, p.68) who published a book entitled Behavior of Organism. This book confirms Skinner as the leading originator of behaviorism in the United States. The theory of language acquisition by Skinner is known as the operant-conditioning theory. This theory of language acquisition is no longer emphasized by the importance of stimulus, but that stimulus which follows response. Suyitno (1990, p.3) states that behavior can be observed based on responses that appear after attracted by stimulus. Behaviorists basically argue that humans are not equipped with innate potential in language acquisition. The human mind is tabula rasa or a blank sheet that will later be filled with the association of stimulus derived from environment and responses outside the organism (Akhadiah et al., 1997, p.63). According to the theory of operant-conditioning, man as a language acquirer is passive and reactive. Instead of being passive and reactive all the time, they are bound to stimulus and reinforcement to behave which come from others. Thus, human verbal behavior as the language acquirer depends on external factors, especially environment, not psychiatry as internal factor. (Saryono, 1991, p.13).

Behavioral psychologists assert that habit has important characteristics. The main reason is habit can be observable. As Watson (1924, p.23) points out, the principle of discovery in real psychology is that its object can be seen, touched, or observed. Watson (1924) rejects the existence of an internal process, because according to him, the mental process is an irrational object, can not be proven, and magical. The habits are automatic. It means that habit can be displayed spontaneously, without much thought and full consciousness (Suyitno, 1990, p.3).

2. Theories of Nativism

The view of nativism as represented by Chomsky (1972) holds that the influence of the surrounding environment is not too important. Chomsky (1972) criticized the operant conditioning theory concerning the process of language acquisition. Skinner (1957) proposes the phenomenon mechanism of a stimulus-response reinforcement in which there is stance, training, and etc. This statement was rejected by Chomsky (1972) that the description of language behavior can not be simply a description of the external stimulus and the corresponding response. The study of language behavior should be a description of the innate human ability to acquire language. Because human has been naturally provided with genetic lingual ability.

The nativist theory holds that there is a strong linkage between biological factors and language development. According to this theory, there is a role of biological evolution in shaping individuals to be a linguistic creature. Along with children's physical and mental growth, language development is also increased and improved.

3. Theories of Cognitivism

According to Piaget in Purwo (1990, p.99), language is not a separate natural feature, but one of several abilities derived from cognitive maturation. The environment does not have much effect on children's intellectual development. Language is structured or controlled by logical reasoning. The development must be based on more fundamental and common changes in cognition. Thus, the sequences of cognitive development determine the sequences of language development.

Piaget in Purwo (1990) asserts that the complex structure of language is not something obtained by nature or learned from its environment. This structure arises as a result of the continuous interaction between cognitive function level of children and the lingual or other environment. Cognitive development is not mere result of organism maturity and environmental influences, but rather the interaction between the two (Gunarsa, 1997, p.136). Piaget (in Purwo, 1990) confirms that there are systems that regulate from within, a biological view, which enable organisms to possess digestive, blood circulatory, respiratory, and others. This is also the case with the cognitive system, the regulating system inside is then influenced by environmental factors. Undoubtedly, cognitive theory emphasizes the working of mental, both comprehension and production. In other words, children's language comprehension is seen as a result of cognitive processes that constantly evolves and changes. Thereupon, stimulus is an input for children which processed in their brain.

\section{Methodology}

This is a qualitative research which describes what is in accordance with the facts contained in the field. Bogdan and Taylor (1992, p.21-22) explain that qualitative research is one of the research procedures which produces descriptive data in the form of speech or writing text and the behavior from the people observed. 
This research design uses qualitative with descriptive method by collecting, classifying, analyzing, interpreting data, and drawing conclusion. Semi (1993, p.23) states that "descriptive research method is not only applied by numbers, but emphasized on the depth of comprehension among the empirical concepts".

Vocabulary mastery is an understanding or ability to use words in language skills both orally and writing. Early-aged children are those from birth until the age of approximately eight years (0-8). This research was conducted in PAUD Melati Makassar, which is located at Jalan Mapala, Makassar City.

The research uses descriptive data which implies vocabulary as the main data is descriptive source by explaining the details of vocabulary mastery of early-aged children. Moreover, the data in this research is collections of speech uttered by early-aged children in the forms of Indonesian vocabularies.

The descriptive research shows the findings by using qualitative descriptive method. The data is obtained and analyzed qualitatively. Direct observations through recording and writing technique are used to obtain the data of speeches produced by the children. The analysis of the research data is based on the transcribed recording and field notes made during the observation.

\section{RESULT}

Indonesian word classes mastered by early-aged children are nouns, verbs, adjectives, adverbs, numerals, pronouns, and prepositions. It is by considering that the quantity of Indonesian vocabulary varies in each child. Based on the data obtained, the vocabulary quantity of girls are more than boys. Those girls are $\mathrm{Na} 109, \mathrm{Rr} 133, \mathrm{Nd} 113, \mathrm{Fa} 115, \mathrm{Rh} 112$, and $A z$ 105. While for boys such as $U w 101, R f 107, R z$ 113, It 110, Di 111, Fd 98, and Zi 107.

TABLE I

INDONESIAN WORD CLASSES MASTERED BY EARLY-AGED CHILDREN

\begin{tabular}{|c|c|c|c|c|c|c|c|c|c|c|}
\hline $\begin{array}{l}\text { Research } \\
\text { Subject }\end{array}$ & $\mathrm{B} / \mathrm{G}$ & Age & & & & & & & & \\
\hline Uw & B & $6^{\text {th }}$ & $\mathrm{N}$ & $\mathrm{V}$ & $\mathrm{A}$ & Adj & Pro & Pre & & Num \\
\hline $\mathrm{Nd}$ & $\mathrm{G}$ & $6^{\text {th }}$ & $\mathrm{N}$ & $\mathrm{V}$ & A & Adj & Pro & Pre & Conj & Num \\
\hline $\mathrm{Rr}$ & $\mathrm{G}$ & $6^{\text {th }}$ & $\mathrm{N}$ & $\mathrm{V}$ & $\mathrm{A}$ & Adj & Pro & Pre & Conj & Num \\
\hline $\mathrm{Rf}$ & B & $6^{\text {th }}$ & $\mathrm{N}$ & $\mathrm{V}$ & $\mathrm{A}$ & Adj & Pro & Pre & Conj & Num \\
\hline $\mathrm{Na}$ & $\mathrm{G}$ & $6^{\text {th }}$ & $\mathrm{N}$ & $\mathrm{V}$ & A & Adj & Pro & & & Num \\
\hline $\mathrm{Fa}$ & $\mathrm{G}$ & $5^{\text {th }}$ & $\mathrm{N}$ & V & & Adj & Pro & & Conj & Num \\
\hline $\mathrm{Rz}$ & B & $6^{\text {th }}$ & $\mathrm{N}$ & $\mathrm{V}$ & & Adj & Pro & Pre & Conj & Num \\
\hline It & B & $6^{\text {th }}$ & $\mathrm{N}$ & $\mathrm{V}$ & & Adj & Pro & & & Num \\
\hline $\mathrm{Ra}$ & $\mathrm{G}$ & $6^{\text {th }}$ & $\mathrm{N}$ & $\mathrm{V}$ & & Adj & & & & Num \\
\hline $\mathrm{Di}$ & B & $6^{\text {th }}$ & $\mathrm{N}$ & $\mathrm{V}$ & & Adj & Pro & Pre & Conj & Num \\
\hline $\mathrm{Fd}$ & B & $6^{\text {th }}$ & $\mathrm{N}$ & $\mathrm{V}$ & & Adj & Pro & Pre & & Num \\
\hline $\mathrm{Az}$ & $G$ & $6^{\text {th }}$ & $\mathrm{N}$ & $\mathrm{V}$ & & Adj & Pro & & & Num \\
\hline $\mathrm{Zi}$ & B & $6^{\text {th }}$ & $\mathrm{N}$ & $\mathrm{V}$ & A & Adj & & Pre & & Num \\
\hline
\end{tabular}

Based on the findings in the field, early-aged children have mastered several scopes of vocabularies among others, kinship, activity, place, number, size, color, universal objects, animal types, and body parts.

There are also five basic pattern of Indonesian sentence found, such as FN-FV, $\mathrm{FN}_{1}-\mathrm{FN}_{2}, \mathrm{FN}-\mathrm{FA}$, FN-Num, and FN- FP. In line with that, here are the following word classes mastered by early-aged children.

\section{A. Noun Class}

Feet, animal, dog, fire, sea, flower, wind, egg, knee, bird, father, tooth, stone, stick, toy, their lockers, their stones, their planes, their cheeks, their body, their hands. Based on the data, it can be seen that early-aged children has known the name of various objects around him. The known objects are generally concrete. Early-aged children initially master noun class because it is often found in everyday life. The noun forms found are original or basic nouns and derivative nouns.

\section{B. Verb Class}

Based on the data found in the field, early-aged children has mastered verb class such as walk, eaten, drunk, recite, thrown, bark, burn, breathe, closed, lick, blown, spin, bind, burned, move, rocking, shopping, sounds, sit, cook, fall, sew, push, be careful, walk, kicked. The verbs mastered by them are verb forms of basic verb. The forms found are original or basic nouns and derivative nouns. The verbs mastered by them are verbs in the basic form, affix verbs, and reduplicated verbs.

\section{Adjective Class}

Several adjectives mastered by early-aged children such as short, slippery, salty, heavy, new, small, long, sick, dirty, hot, tight, beautiful, tall, funny, allergy, quick. The adjectives found are in the basic and iterative form.

\section{Adverb Class}

Vocabularies related to adverbs found in the data include must, already, also, can, ever. The word ever becomes the aspect marker, while the modality marker by the word of already. 


\section{E. Pronoun Class}

The vocabularies associated with pronoun is saya, engkau, kita, -ku, nya, -mu (me, you, us, my-, it, your-). Personal pronouns found are saya, engkau, kita, kaтu. While demonstrative pronouns found are itu (that) and ini (this). The possessive pronouns which state ownership are $-k u, n y a, m u-$.

\section{F. Numeral Class}

In numeral class, there are one, two, three, four, five, many, few. The vocabularies of one, two, three, four, lima are main definite numeral words, while many and few are are main indefinite numeral words.

\section{G. Preposition Word Class}

In the preposition word class, the vocabularies found are for, in, from, with, to, than, and. Word in, and are indicated as the prepositions of location and time. Word to indicates location or place, while with is the preposition for tool and means. Than is the preposition of comparison and to indicates recipient or purpose.

\section{H. Word Class of Conjuction}

The words of conjunction found are because and if which become as subordinating conjunctions. While or and but are coordinating conjunction.

\section{The Scopes of Indonesian Vocabularies Mastered by Early-aged Children}

Based on the findings in the field, early-aged children have mastered several scopes of Indonesian vocabularies as follows:

1. Kinship;

2. Activities;

3. Place/Location;

4. Numbers;

5. Sizes;

6. Colors;

7. Universal Objects;

8. Animal Types;

9. Body Parts

\section{DISCUSSION}

In this research, the quantity of children varies from one to another. Among six girls observed, the vocabulary mastered are in the range of 112 to 133 vocabularies, while the seven boys in the range of 98 to 113 vocabularies. Several factors caused the differences are internal and external factors. It is showed that girls have more vocabulary than boys. They are more open-minded, braver, more talkative, rather than boys with introvert behavior.

Early-aged children only master the vocabulary majority which associate with activities and concrete words such as egg, fish, fruit, walk, burn and so forth. Early-aged children are still unable to comprehend abstract words such as fat, tall, and etc.

The scopes of the vocabulary mastered by early-aged children include kinship, body parts, pronouns, numeral, and main verbs as basic vocabulary. The increasing age makes the mastery of a child's vocabulary will also increase along with their language experience. However, each child with their own unique characteristics creates individual's differences in vocabulary amount they acquire at their own age respectively.

The findings show that early-aged children have used five patterns of basic sentence. As Samsuri points out that in Indonesian language, there are five patterns of basic sentence, such as a) FN-FV; b) FN1-FN2; c) FN-FA; d) FNFNum; and e) FN-FP.

In line with that, the findings also show that the children have mastered five patterns of basic sentence related to the earlier statement by Samsuri. The sentences used by early-aged children have structural alignment with English sentences tested by Chomsky to 40 kindergarten children in the US.

Several sentences mastered by early-aged children are relatively simple sentences with transitional construction which indicate that the arranging rules are not yet fully as sentences used by adults. Based on the data, the sentences used by those early-aged children are active and declarative sentence. The characteristics of children's basic sentence considered by the integrative phrase that is $F N-F V$ and transitive and intransitive verb are found in those early-aged children's sentences.

The findings show that $F N-F V$ integrative phrase are still simple because it still uses an old simple form. By observing the data, there are not much inflectional morphemes. It is not because those early-aged children do not use complex morpheme yet, but they are still in stage of trial.

\section{CONCLUSION}


The quantity of vocabulary varies from one to another. This is due to several factors such as external factors of different family backgrounds. In addition, girls have more vocabularies than boys.

Early-aged children have mastered Indonesian word classes, such as nouns, verbs, adjectives, adverbs, numerals, pronouns, conjunctions, and prepositions. The most dominant word classes mastered by them is noun class due to its concrete. The scopes of Indonesian vocabularies mastered by early-aged children include kinship, activity, place, number, size, color, universal objects, animal types, and body parts.

Based on the data obtained, the findings of this research show that early-aged children in PAUD Melati Makassar have mastered five patterns of basic sentence such as: a) FN-FV; b) FN1-FN2; c) FN-FA; d) FN-FP; and e) FNFNum.

\section{REFERENCES}

[1] Akhadiah, Sabarti dkk. (1991). Pengajaran Kosakata. Jakarta: Dikti.

[2] Chomsky, Noam. (1971). Syntactic Structures. The Hague: Mouton \& CCo.

[3] Hamboro, H. (1995). Penguasaan Perbendaharaan Kata Ditinjau dari Interaksi Sosial. Skripsi. (tidak diterbitkan). Yogyakarta: Fakultas Psikologi Universitas Gadjah Mada.

[4] Hartati, Sofia. (2005). Perkembangan Belajar Anak Usia Dini.Jakarta: Gramedia.

[5] Jamaris, Martini. (2005). Perkembangan dan Pengembangan Anak Usia Taman Kanak-kanak. Jakarta: Gramedia.

[6] Mansur. (2005). Pendidikan Anak Usia Dini dalam Islam. Yogyakarta: Pustaka Pelajar.

[7] Musthafa, Bacharuddin. (2007). Early Childhood Care and Education IndonesiaCurrent Practice and Future Policy Directions. Bandung: SPS-UPI.

[8] Mulyasa, H.E. (2012). Manajemen PAUD. Bandung : Remaja Rosdakarya.

[9] Piaget, Jean. (1959). The Language and Thought of the Child. New York: The New American Library Ltd.

[10] Ramli. T. (2005). Pendidikan Karakter, Bandung: Angkasa.

[11] Samsuri. (1994). Analisis Bahasa. Jakarta: Erlangga.

[12] Santrock, John W. (1995). Life-Span Development; perkembangan Masa Hidup. Jakarta: Erlangga.

[13] Saryono. (1992). Beberapa Teori Pemerolehan Bahasa. Malang: Departemen Pendidikan dan Kebudayaan Malang.

[14] Skinner. (1957). Verbal Behavior. New York. Appleton Century Crofts, Inc.

[15] Suyitno, Imam. (1990). Teori Belajar Bahasa. Malang: Departemen Pendidikan dan Kebudayaan Malang.

[16] Tarigan, Henry Guntur. (1984). Psikolinguistik. Bandung: Angkasa.

Asia, student of Bahasa Study Program of postgraduate Universitas Negeri Makassar. As Lecturer of the Faculty of language and literature of IKIP/Makassar State University year 2000 till now, born in Makassar City, Agustus 28, 1969. elementary schools in the national primary school in Makassar in 1992. JUNIOR HIGH SCHOOL at SMP Negeri 1 in Makassar, in 1995. Senior High school in SMA Negeri 3, Makassar in 1998. S-1 IKIP Ujung Pandang year 1994, Then completed S-2 FPs IKIP Malang 2001.

Achmad Tolla, Lecturer of the Faculty of language and literature of IKIP/Makassar State University year 1982 till now, born in Leling Mamuju Regency, March 21, 1949. Completed primary school education Affairs Leling year 1966, the first State secondary school of the year 1968, Mamuju, Mamuju Sman 1970, B.a. IKIP Ujung Pandang years 1979, S-1 IKIP Ujung Pandang year 1981, Then completed S-2 FPs IKIP Malang 1991. Won a doctorate FPs Ikip Malang in 1996.

The experience of the Office, the head of the laboratory of FBS IKIP Ujung Pandang years 1996-1997, Secretary of the Program S-2 PPs IKIP Ujung Pandang years 1997-2001, Assistant Dean UNM FBs year 2001-2004 III, Chairman of the Indonesian Language Education 2004-2005 years, UNM Head UPBJJ UT West Sulawesi years 2005-2008, Chairman of the Doctoral Program of the science of language education PPs UNM year 2009 s. d now, Presiding Professor State University of Makassar.

Salam, As Lecturer of the Faculty of language and literature of IKIP/Makassar State University year 1989 till now, born in Parepare City, June 28, 1963. S-1 IKIP Ujung Pandang year 1986, Then completed S-2 FPs IKIP Malang 1988. 